\title{
Development of obesity from childhood to adolescents
}

Rozwój otyłości od dzieciństwa do wieku młodzieńczego

\author{
${ }^{1}$ Anna Majcher, ${ }^{2}$ Aneta Czerwonogrodzka-Senczyna, ${ }^{1}$ Katarzyna Kądziela, ${ }^{1}$ Małgorzata Rumińska, \\ ${ }^{1}$ Beata Pyrżak
}

${ }^{1}$ Department of Paediatrics and Endocrinology, Medical University of Warsaw, Poland

${ }^{2}$ Clinical Dietetics Department, Medical University of Warsaw, Poland

\begin{abstract}
Introduction: Obesity is a major health problem in Poland and around the world. Excessive gain in early childhood is an important risk factor for the development of obesity.

The aim of the study was to analyze the prevalence of obesity in 2-, 4- and 6-year-old obese children.

Material and methods: The study group: 656 overweight and obese children aged 5-18 years old. The patients' height and weight were measured, body mass index (BMI) was calculated. Overweight: BMI between $85^{\text {th }}-97^{\text {th }}$ percentile and obesity: BMI $>97^{\text {th }}$ were defined using World Health Organization. BMI $<+2$ SDS as overweight, BMI $\geq+2$ SDS as class I obesity, and BMI $\geq 3$ SDS as class II. Measurements from the health books of children aged $2(n=626), 4(n=533)$ and $6(n=518)$ years old were analyzed.

Results: Mean age: $12.25 \pm 2.90$ years, BMI SDS: +2.54 \pm 0.60 . There were 100 overweight (15.2\%) and 556 obese (84.8\%) children in the group, including 143 patients with class II obesity (21.8\%). Children < 10 years old comprised 28\%. It was established that $36.6 \%$ of the patients were overweight or obese at the age of 2 years old. At the age of 4 , the percentage was $73.9 \%$, and at the age of 6 , it was as high as $84 \%$.
\end{abstract}

\section{Conclusions:}

1. The children studied had excess body weight from early childhood. The prevalence of obesity increased with age.

2. Systematic monitoring of developmental parameters in children is essential from an early age.

\section{Key words:}

obesity, children, prevention.

\section{Streszczenie}

Wprowadzenie: Otyłość w Polsce i na świecie jest istotnym problemem zdrowotnym. Nadmierny przyrost masy ciała we wczesnym dzieciństwie to ważny czynnik ryzyka rozwoju otyłości.

Cel pracy: Analiza występowania nadmiernej masy ciała w wieku 2, 4 i 6 lat u dzieci z otyłością.

Materiał i metody: Grupa badana to 656 dzieci w wieku 5-18 lat z nadwagą i otyłością. U pacjentów mierzono wysokość, masę ciała i wyliczono wskaźnik masy ciała (body mass index - BMI). Nadwagę (BMI powyżej 85.-97. centyla) i otyłość: (BMI > 97. centyla) definiowano wg norm Światowej Organizacji Zdrowia. Za nadwagę przyjęto BMI $<+2$ SDS, za otyłość $\mathrm{I}^{\circ}$ BMI $\geq+2$, za otyłość II $\mathrm{BMI} \geq 3$. Analizowano pomiary z książeczek zdrowia dzieci w wieku $2(n=626), 4(n=533)$ i $6(n=518)$ lat.

Wyniki: Średni wiek pacjentów wynosił 12,25 $\pm 2,90$ roku, BMI w SDS: $+2,54 \pm 0,60$. W grupie było 100 dzieci z nadwagą (15,2\%) i 556 z otyłością $(84,8 \%)$, u 143 pacjentów (21,8\%) występowała otyłość II stopnia. Dzieci < 10 lat stanowiły 28\% grupy. Stwierdzono, że w wieku 2 lat nadwagę lub otyłość miało 36,6\% pacjentów. W wieku 4 lat odsetek wynosił 73,9\%, w wieku 6 lat już 84\%.

\section{Wnioski:}

1. U badanych dzieci nadmierna masa ciała występowała od wczesnego dzieciństwa. Częstość otyłości wzrastała z wiekiem.

2. Niezbędne jest systematyczne monitorowanie parametrów rozwojowych u dzieci od najmłodszych lat.

\section{Słowa kluczowe:}

dzieci, otyłość, profilaktyka. 


\section{Introduction}

Obesity in children and adolescents is a growing health problem on a global scale. According to data published in 2017, the percentage of children with obesity increased eightfold between the years 1975 and 2016, and their total number in 2016 was 41 million [1-5].

In Poland, the prevalence of overweight and obesity in children and adolescents is a widely researched topic. Studies have reported the occurrence of obesity in increasingly younger age groups [6-10].

Most (80-90\%) developmental age patients admitted for a diagnosis of overweight and obesity are adolescents with metabolic disorders: carbohydrate and/or lipid metabolism disorders, hypertension, insulin resistance, and metabolic syndrome. Infancy and adolescence are thought to be "critical periods" for the development and persistence of obesity. Rapid and excessive weight gain in early childhood increases the risk of obesity developing, with significant, ever-increasing health complications in adulthood as well as in adolescence. It is vital that prevention of obesity should begin in early childhood [5, 10-16]. Members of the European Childhood Obesity Group (ECOG) request that large-scale projects promoting a healthy lifestyle and weight control be undertaken, with the participation of the media and a wide range of medical specialists $[2,3,10,17,18]$.

\section{The aim of the study}

The aim of the study was to evaluate the development of excess body weight in the early childhood based on the 2-, 4- and 6-year-olds health balance in children and adolescents hospitalized due to overweight and obesity".

\section{Material and methods}

The study was conducted in children and adolescents admitted to the Department of Pediatrics and Endocrinology of the Medical University of Warsaw due to overweight and obesity between 2002-2020 (19 years' follow-up). According to our exclusion criteria we included to the study 656 patients (332 boys and 324 girls) out of 3320 overweight and obese children aged $5-18$ years (which is about $12 \%$ of all patients hospitalized in our endocrinology department).

All qualified children were medically examined, their height and weight were measured. Secondary obesity was excluded. Measurements were taken in the anthropometric laboratory by one person, in accordance with standard anthropological methodology. Height and body weight were used to calculate the body mass index (BMI), which was standardized in line with WHO guidelines (2007). Overweight and obesity were defined using growth charts: $85^{\text {th }}-97^{\text {th }}$ percentile and $>97^{\text {th }}$ percentile, respectively. BMI values were converted to normalized data (BMI SDS) (19). BMI > + 1 SDS was classified as overweight, $\mathrm{BMI} \geq+2$ SDS as class I obesity, and BMI $\geq 3$ SDS as class II obesity. Information concerning the height and weight of the children as measured during routine check-ups at the ages of 2, 4 and 6 was obtained from their health record books. We took to analysis only children, who had a minimum of two such examinations. Overweight and obesity were assessed for every age group. The increases in the children's height and weight and BMI values in subsequent studies were analyzed. The resulting data were compared to the mean height gain and weight gain according to current reference values for the Polish population. It was verified whether there was a relationship between overweight/obesity and the child's gender. The data were processed using the MS Excel 2007

\section{Results}

In the study group, the mean BMI SDS was $+2.54 \pm 0.6$, the mean BMI was $27.56 \pm 3.85 \mathrm{~kg} / \mathrm{m}^{2}$. One hundred children (15.2\%) were diagnosed with overweight, and 556 patients (84.8\%) with obesity. Class II obesity (BMI $\geq+3$ SDS) was found in 143 patients (21.8\%).

The mean calendar age of the participants was 12.25 \pm 2.90 years (the youngest being 5 and the oldest being 18 years old). Twenty eight percent of the children were younger than 10 years old, including 10 children $<7$ years old. Obesity was found in as many as $94 \%$ of this group. The largest group was children from 10 to 15 years old, and $86.5 \%$ of them were obese. The group of children $>15$ years old was characterised by the highest percentage of overweight: $33.1 \%$ (Table I).

The number of children with class II obesity decreased with age $(42.6 \%$ vs. $17.1 \%$ vs. $5.3 \%)$, although $12 \%$ of patients in the oldest age group reached a body weight of $>110 \mathrm{~kg}$, and the maximum body weight in one of them was $150.4 \mathrm{~kg}$.

Anthropometric measurements for the ages of 2, 4 and 6 years old were obtained for $95.4 \%, 81.2 \%$ and $79 \%$ of the participants respectively. At the age of 2 years old, 82 children (13.1\%) were overweight and 147 patients (23.5\%) were obese. At the age of 4 years, 170 children (31.9\%) were overweight, while $224(42 \%)$ were obese. At the age of 6, overweight was found in 170 (32.8\%) patients, and obesity in as many as 265 (51.2\%). In total, excess body weight was found in $36.6 \%$ of patients aged 2 , in $73.9 \%$ at the age of 4 , and in $84 \%$ of children aged 6 years old (Table II).

In the period between the ages of 2 and 6 years old, the mean body weight gain in the patients was $15.6 \mathrm{~kg} / 4$ years (while the median was $12 \mathrm{~kg}$ ). The maximum weight gain was $35.9 \mathrm{~kg} / 4$ years, and weight gain over $20 \mathrm{~kg}$ was found in 89 children (17\%). Large height gains were found in the study group. The mean height gain between check-ups at the age of 2 and 6 was $32.4 \mathrm{~cm}$. The mean growth rate was approximately $8 \mathrm{~cm} /$ year, but growth rate of over $12 \mathrm{~cm} /$ year $(55 \mathrm{~cm} / 4$ years) was also recorded.

Very large weight gains were observed between the ages of 2 and 4 (in 64 children weight gain was > $10 \mathrm{~kg} / 2$ years, the maximum weight gain was $24 \mathrm{~kg}$ ). Between the ages of 4 and 6 , weight gain was over $10 \mathrm{~kg} / 2$ years in 125 patients, over $20 \mathrm{~kg} / 2$ years in 3 patients, with the maximum gain as high as $28 \mathrm{~kg}$. 
Table I. Study group characteristics $(n=656)$

\begin{tabular}{llll}
\hline Calendar age & $<10$ years & $10-15$ years & $>15$ years \\
\hline Number $(n)$ and $(\%)$ & 183 & 340 & 133 \\
& $(28 \%)$ & $(51.8 \%)$ & $(20.2 \%)$ \\
\hline Mean BMI w SDS & +3.111 .19 & +3.01 .16 & +3.021 .13 \\
\hline Overweight & 11 & 46 & 44 \\
$n(\%)$ & $(6 \%)$ & $(13.5 \%)$ & $(33.1 \%)$ \\
\hline Obesity I $_{n(\%)}$ & 94 & 236 & 82 \\
\hline Obesity $\|^{\circ}$ & $(51.4 \%)$ & $(69.4 \%)$ & $(61.6 \%)$ \\
$n(\%)$ & 78 & 58 & 7 \\
\hline & $(42.6 \%)$ & $(17.1 \%)$ & $(5.3 \%)$ \\
\hline
\end{tabular}

Table II. Number and percentage of patients with overweight and obesity in check-ups at particular ages

\begin{tabular}{llllll}
\hline Age/number & Overweight $(n)$ & Obesity $(n)$ & Overweight (\%) & Obesity (\%) & All (\%) \\
\hline $\begin{array}{l}2 \text { years old } \\
(n=626)\end{array}$ & 82 & 147 & 13.1 & 23.5 & 36.6 \\
\hline $\begin{array}{l}4 \text { years old } \\
(n=533)\end{array}$ & 170 & 224 & 31.9 & 42.0 & 73.9 \\
\hline $\begin{array}{l}6 \text { years old } \\
(n=518)\end{array}$ & 170 & 265 & 32.8 & 51.2 & 84.0 \\
\hline
\end{tabular}

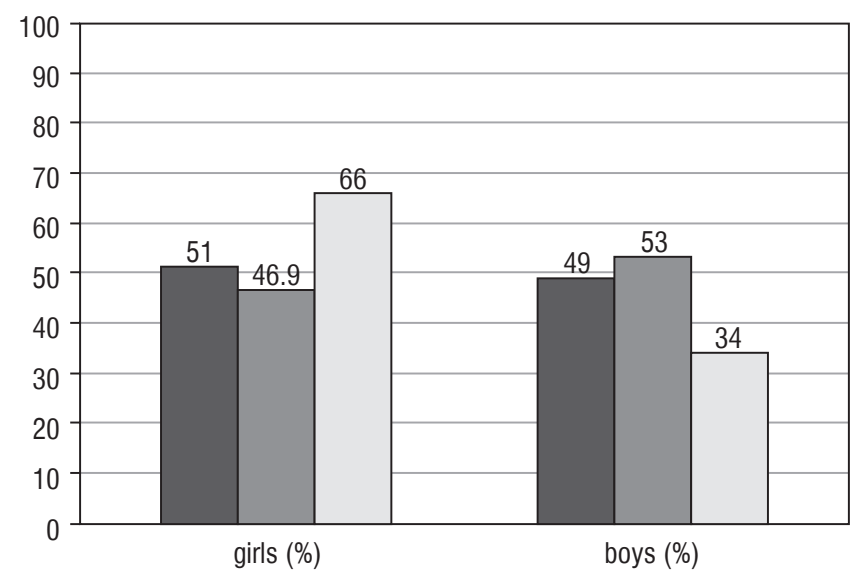

2 years $\quad \square 4$ years $\quad \square 6$ years

Figure 1. Percentage of obese children aged 2, 4 and 6 by gender (\%)
In the 6-year-olds' check-ups, obesity was more common in girls than in boys (175 vs. 90 cases). No such difference was found at the age of 2 years old. A tendency for overweight was already visible in 4-year-old girls $(p>0.05)$ (Fig. 1).

\section{Discussion}

Poland is one of the countries where the prevalence of overweight and obesity in children and adolescents is below $15 \%$. According to Kułaga et al. [8], in large-scale randomized studies including over 5000 children, obesity was found in $4.9 \%$ of boys and $3.4 \%$ of girls between the ages of 2 and 6 , while the total percentage of children with excess body weight (after the inclusion of overweight, according to $\mathrm{WHO}$ guidelines) was $12 \%$ and $10 \%$ respectively.

Our observations indicate that over $36 \%$ of patients admitted to the Department of Endocrinology with excess body weight were obese at the age of 2 , and this percentage increased with age (at 4 and 6 years old). This is in line with many authors from around the world reporting an ever-earlier onset of obesity: in Australia 1 in 5 children aged 2-3 years old and 1 in 
3 children aged 2-5 have excess body weight, in England in 2016 overweight or obesity was found in $11 \%$ of children aged 2-4 years, in $20 \%$ of children aged $4-5$ years and in as many as $30 \%$ of children aged 11 years $[2,4,5]$.

Among the causes of overweight and obesity in young children which have been cited are low birth weight, short duration of breastfeeding, early introduction of sweet foods into infants diet and lack of parental knowledge about the principles of healthy nutrition $[6,7,9,17]$

An American study (Maher et al. 2008) which was based on the nationwide programme Early Childhood Longitudinal Study - Kindergarten Cohort (ECLS - K) found a 12\% prevalence of obesity among first-time preschoolers. Obesity was less frequent in children who had attended care institutions than in those who had been cared for by their parents or guardians [20]. A Canadian study within the framework of the Better Beginnings, Better Futures programme assessed 760 children from Ontario, ranging from preschool age to the $3^{\text {rd }}$ grade of primary school. It was found that $68.2 \%$ of children whose $\mathrm{BMI}$ was $>85^{\text {th }}$ percentile in kindergarten had a $\mathrm{BMI}>95^{\text {th }}$ percentile in the $3^{\text {rd }}$ grade. The prevalence of overweight increased during that period from $9.9 \%$ to $15.2 \%$ [21]. In the present study, the highest percentage of children with class II obesity (42.6\%) occurred in the youngest group of children ( $<10$ years old) and was probably the reason for the early referral of the child to a specialist.

Initially, intervention programmes aimed at obese children targeted school age groups. Due to unsatisfactory results, and in line with WHO recommendations emphasising the importance of preventative measures, more and more programmes are currently addressed to parents and guardians of children in the youngest age groups. The core principle of most such programmes is promoting a healthy lifestyle, which includes: proper nutrition, physical activity and changes in daily routine (less "screen time"). Simple, yet effective programmes are being developed that use modern technology, e.g. computer programmes, applications, support via text reminders [22, 23].

Positive effects of such programmes have been reported by researchers from various parts of the world. In Thailand, a three-year nutrition education programme conducted in several kindergartens resulted in a significant decrease in the percentage of overweight and obese children [24]. In France, following a two-year educational programme addressed to the teachers and parents of preschool children, a lower BMI increase was found in those children compared to a control group [25]. A large study based on a programme developed at the University of Manchester was conducted in England in 2013-2017 (Children's Health and Monitoring Programme). It included children aged 4-11 years old, whose height and weight were measured on a yearly basis. The novelty of the programme consisted in using an application which made it possible to send the parents information about the child's measurement results, along with an interpretation of their BMI and advice on the principles of a healthy lifestyle [23]. Positive effects were reported in the group using the application. In the UK, Hodgkinson et al. conducted a study to which 2-year-old children attending nurseries and their mothers were recruited.
Trained personnel provided education using activities and materials in the form of games and stories about health heroes (Healthy Heroes). They were related to diet and physical activity, encouraging changes in lifestyle and dietary habits. Height and weight measurements were taken every 6 months up to the age of 4 . A decrease in BMI was documented in children from the study group, while in children from the control group the BMI value increased [5]. According to a study by American researchers (Tucker, 2019), a 6-month pro-health behaviours scheme led to a reduction in "screen time", an improvement in dietary habits and an increase in physical activity [26]. In 2019, Pan et al. published the results of a very extensive programme, conducted in all the states of the USA between 2010 and 2016, facilitating healthy nutrition of women, infants and children (Special Supplemental Nutrition Program for Women, Infants and Children). Most of the states (73\%) demonstrated a decrease in the prevalence of obesity in the group of 2- to 4-year-old children enrolled in the program. It must be noted that at the same time the USA saw a significant increase in the number of obese children in this age group [27]

In Poland, endocrinologists and dietitians have long been drawing attention to the problem of obesity in children $[2,6-10,17]$. The Polish National Health Programme took account of the guidelines set out in the European Charter on Counteracting Obesity (2006), which were implemented with the participation of the National Food and Nutrition Institute as POL-HEALTH [28]. They urged instigating education of various social groups, including those associated with health protection, and education of children and adolescents. The programme was conducted in the years 2007-2011 [28, 29]. Also noteworthy are the actions of researchers from the leading institutes, such as The Children's Memorial Health Institute - "The ToyBox Study Group", Institute of Mother and Child - activities in the OECD, the National Food and Nutrition Institute - popularization of healthy nutrition, and Medical Universities, along with nutrition associations and societies: Polish Society of Dietetics, Polish Association of Dietitians [3, 7, 30-32]. Local government initiatives to counteract obesity in children have also been launched. In Warsaw, the "I know what I eat" campaign is in place, launched by the City of Warsaw, involving educational institutions and aimed at, among others, children aged 6-9 years old. There is also an educational campaign underway (already in its $11^{\text {th }}$ edition) in favour of drinking water: "Mum, Dad, I prefer water", prepared by mineral water producers, under the auspices of the Ministry of Health and leading paediatric centres in the country, providing valuable educational materials for shaping proper nutrition habits among the youngest [29]. Tangible effects of these actions can already be observed.

The study by Żegleń et al. assessed the prevalence of obesity in children aged 3 to 7 years old in Krakow in the years 2008 to 2018 and no increase in the prevalence of excess body weight was found in the decade in question [33]. In Wroclaw, 230 children aged 6 years were observed and it was found that approx. $10 \%$ of them had excess body weight (8.2\% were overweight and $1.7 \%$ were obese) [34]. In a study from Gdansk, where the authors investigated the prevalence of overweight in 
over 70,000 children aged 6 to 13 years, it did not increase over a period of 20 years, between 1992 and 2012 [35].

A prerequisite to undertake any intervention is awareness of abnormalities in the child's nutrition and development. Fastgrowing children, crossing consecutive body height percentile channels, should be subject to more frequent anthropometric monitoring, even if their BMl remains at a constant level. It is well-known that increased insulin secretion causes growth acceleration thanks to its action on the insulin-like growth factor (IGF-1) receptor. This fact is supported by our material, where significant increases in height between 2 and 6 years of age were found in some obese children, with growth rate averaging approx. $8 \mathrm{~cm} /$ year and even reaching above $12.5 \mathrm{~cm} /$ year.

Younger children are still not referred to a specialist often enough. Among our patients, children $<10$ years old comprised only $28 \%$ of the study group, while overweight and obesity were already found in $36.6 \%$ of children aged two, and this percentage increased with age (it was $73.9 \%$ at the age of 4 and $84 \%$ at the age of 6 ).

In everyday practice, BMI is rarely determined for the youngest children, and often the results obtained are not compared to population norms. In Poland, currently issued health record books contain body weight and BMl growth charts for young children (according to the WHO), and from 3 to 18 years of age, body height, weight and BMI charts for the Polish population

\section{References}

1. de Onis M., Blossner M., Borghi E. Global prevalence and trends of overweight and obesity among preschool children. Am J Clin Nutr 2010; 92: 1257-1264. doi: 10.3945/ajcn.2010.29786.

2. Małecka-Tendera E., Mazur A. Childhood obesity: a pandemic of the twenty-first century. Int J Obes (Lond) 2006; 30, suppl 2: S1-3. doi: 10.1038/sj.ijo.0803367.

3. NCD Risk Factor Collaboration (NCD-RisC): Worldwide trends in body-mass index, underweight, overweight, and obesity from 1975 to 2016: a pooled analysis of 2416 population-based measurement studies in 128.9 million children, adolescents, and adults. Lancet 2017; 390: 2627-2642. doi: 10.1016/S0140-6736(17)32129-3.

4. Wen LM, Rissel C, Xu H, et al. Linking two randomised controlled trials for Healthy Beginnings (C): optimising early obesity prevention programs for children under 3years. BMC Public Health 2019; 19 : 739. doi: 10.1186/s12889-019-7058-9.

5. Hodgkinson A, Abbott J, Hurley MA, et al. An educational intervention to prevent overweight in pre-school years: a cluster randomised trial with a focus on disadvantaged families. BMC Public Health 2019; 19: 1430. doi: 10.1186/s12889-019-7595-2.

6. Czerwonogrodzka-Senczyna A., Kryńska P., Majcher A, et al. Wpływ czynników środowiskowych na występowanie otyłości u dzieci do 7 roku życia. Endokrynol Ped 2014; 2: 17-24.

7. Fijałkowska A, Oblacińska A, Stalmach M. Nadwaga i otyłość u polskich 8-latków w świetle uwarunkowań biologicznych, behawioralnych i społecznych. Raport międzynarodowych badań WHO (according to the OLA and OLAF project). The values recommended for diagnosing overweight are $\mathrm{BMI}>85^{\text {th }}$ percentile, and for obesity $\mathrm{BMI}>97^{\text {th }}$ percentile $[8,19]$. Many researchers note the usefulness of measuring waist circumference, which is a good marker in the assessment of adipose tissue distribution, also in preschool children [36-38]. Percentile distributions of this parameter for children and adolescents are available in Poland [38-40].

If any abnormalities in the physical development of a child are found during a regular check-up, it is advisable to perform more frequent anthropometric measurements. One should calculate the patient's BMI, measure their waist circumference and then evaluate these indicators using growth charts, give them advice on healthy nutrition and provide them with early specialist care in order to normalize their weight.

\section{Conclusions}

The children studied had excess body weight from early childhood. The prevalence of overweight and obesity increased with age.

Systematic monitoring of developmental parameters in children is essential from an early age, and if any abnormalities are found, an urgent referral to a specialist and starting educational and training programmes are necessary.
European Childood Obesity Sureillance Initative (COSI). Wyd. Instytut Matki i Dziecka, Warszawa 2017.

8. Kułaga Z, Gurzkowska B, Grajda A, et al. The prevalence of overweight and obesity among Polish pre-school-aged children. Dev Period Med 2016; 20: 143-149.

9. Baran J, Weres A, Czenczek-Lewandowska E, et al. Early eating patterns and overweight and obesity in a sample of preschool children in South-East Poland. Int J Environ Res Public Health 2019; 16: 3064. doi: 10.3390/ijerph16173064.

10. Januszek-Trzciąkowska A, Małecka-Tendera E, Klimek K, Matusik P. Obesity risk factors in a representative group of Polish prepubertal children. Arch Med Sci 2014; 10: 880-885. doi: 10.5114/ aoms.2013.33328.

11. de Onis M. Preventing childhood overweight and obesity. J Pediatr (Rio J) 2015; 91: 105-107. doi: 10.1016/j.jped.2014.10.002.

12. Rito $\mathrm{Al}$, Buoncristiano $M$, Spinelli $A$, et al Association between Characteristics at Birth, Breastfeeding and Obesity in 22 Countries: The WHO European Childhood Obesity Surveillance Initiative - COSI 2015/2017. Obes Facts 2019; 12: 226-243. doi: 10.1159/000500425.

13. Dubois L, Girard M. Early determinants of overweight at 4,5 years in a population-based longitudinal study. Int J Obes (Lond) 2006; 30: 610-617. doi: 10.1038/sj.ijo.0803141.

14. Blomquist $H_{\text {., }}$ Bergstrom E. Obesity In 4-year-old children more prevalent in girls and in municipalities with a low socioeconomic level. Acta Paediatr 2007; 96: 113-116. doi: 10.1111/j.16512227.2006.00018.x. 
15. Del-Rio-Navarro BE, Velazquez-Monroy O, Lara-Esqueda A, et al: Obesity and metabolic risks in children. Arch Med Res 2008; 39: 215-221. doi: 10.1016/j.arcmed.2007.07.008.

16. Blundell JE, Baker JL, Boyland E, et al. Variations in the Prevalence of Obesity Among European Countries, and a Consideration of Possible Causes. Obes Facts 2017; 10: 25-37. doi: 10.1159/000455952.

17. Mazur A, Caroli M, Radziewicz-Winnicki I, et al. Reviewing and addressing the link between mass media and the increase in obesity among European children: The European Academy of Paediatrics (EAP) and The European Childhood Obesity Group (ECOG) consensus statement. Acta Paediatr 2018; 107: 568-576. doi: 10.1111/ apa.14136.

18. Caroli M, Malecka-Tendera E, Epifani S, et al. Physical activity and play in kindergarten age children. Int J Pediatr Obes. 2011; 6 Suppl 2: 47-53. doi: 10.3109/17477166.2011.613671.

19. www.who.int

20. Maher EJ, Li G, Carter L, Johnson DB. Preschool child care participation and obesity at the start of kindergarten. Pediatrics 2008; 122: 322-330. doi: 10.1542/peds.2007-2233.

21. Evers S, Arnold R, Hamilton T, Midgett C. Persistence of overweight among young children living in low income communities in Ontario. J Am Coll Nutr 2007; 26: 219-224. doi: 10.1080/ 07315724.2007.10719604.

22. Ek A, Delisle Nyström C, Chirita-Emandi A, et al. A randomized controlled trial for overweight and obesity in preschoolers: the More and Less Europe study - an intervention within the STOP project. BMC Public Health. 2019; 19: 945. doi: 10.1186/s12889-019-7161-y.

23. Dam R, Robinson HA, Vince-Cain S, Heaton G, et al. Engaging parents using web-based feedback on child growth to reduce childhood obesity: a mixed methods study. BMC Public Health. 2019; 19: 300. doi: 10.1186/s12889-019-6618-3.

24. Ratanachu-ek S, Moungnoi P. The effect of teacher education on the prevalence of obesity in kindergarten children. Med Assoc Thai 2008; 91 Suppl 3: S 152-156.

25. Jouret B, Ahluwalia N, Dupuy M, et al. Prevention of overweight in preschool children: results of kindergarten-based interventions. Int J Obes (Lond). 2009; 33: 1075-1083. doi: 10.1038/ijo.2009.166.

26. Tucker JM, DeFrang R, Orth J, et al. Evaluation of a Primary Care Weight Management Program in Children Aged 25 years: Changes in Feeding Practices, Health Behaviors, and Body Mass Index. Nutrients 2019; 11: 498. doi: 10.3390/nu11030498.

27. Pan L, Blanck HM, Park S, et al. State-Specific Prevalence of Obesity Among Children Aged 2-4 Years Enrolled in the Special Supple- mental Nutrition Program for Women, Infants, and Children - United States, 2010-2016. MMWR Morb Mortal Wkly Rep 2019; 68: 10571061. doi: 10.15585/mmwr.mm6846a3.

28. www.izz

29. www.gov.pl/web/zdrowie

30. Miguel-Berges ML, Santaliestra-Pasias AM, Mouratidou T, et al., Group OBOTT. Combined Longitudinal Effect of Physical Activity and Screen Time on Food and Beverage Consumption in European Preschool Children: The ToyBox-Study. Nutrients 2019; 11 1048. doi: 10.3390/nu11051048.

31. ptd.org.pl

32. www.psdiet.pl

33. Żegleń M, Kryst $Ł$, Kowal M, et al. Changes in the prevalence of overweight/obesity and adiposity among pre-school children in Kraków, Poland, from 2008 to 2018. J Biosoc Sci 2020; 52: 895906. doi: 10.1017/S0021932019000853.

34. Czajka K, Kolodziej M. Parental perception of body weight in preschool children and an analysis of the connection between selected parent-related factors and the assessment of their children's weight. Dev Period Med 2015; 19 (3 Pt 2): 375-382.

35. Brzeziński $M$, Jankowski $M$, Jankowska $A$, et al. Is there a rapid increase in prevalence of obesity in Polish children? An 18-year prospective observational study in Gdansk, Poland. Arch Med Sci 2018; 14: 22-29. doi: 10.5114/aoms.2018.72239.

36. Poeta M, Lamberti R, Di Salvio D, et al. Waist Circumference and Healthy Lifestyle Preferences/Knowledge Monitoring in a Preschool Obesity Prevention Program. Nutrients 2019; 11: 2139. doi: 10.3390/nu11092139.

37. Roswall J, Bergman S, Almqvist-Tangen G, et al. Population-based waist circumference and waist-to-height ratio reference values in preschool children. Acta Paediatr 2009; 98: 1632-1636. doi: 10.1111/j.1651-2227.2009.01430.x.

38. Xi B, Zong X, Kelishadi R, et al. International waist circumference cutoffs for central obesity in children and adolescents aged 6 to 18 years. J Clin Endocrinol Metab 2020; 105: e1569-1583. doi: 10.1210/clinem/dgz195.

39. Nawarycz LO, Krzyzaniak A, Stawińska-Witoszyńska B, et al. Percentile distributions of waist circumference for 7-19-year-old Polish children and adolescents. Obes Rev 2010; 11: 281-288. doi 10.1111/j.1467-789X.2009.00694.x.

40. Nawarycz T, Haas GM, Krzyżaniak A, et al. Waist circumference and waist-to-height ratio distributions in Polish and German schoolchildren: comparative analysis. Int J Prev Med 2013; 4: 786-796. 